\title{
TEOPИЯ
}

Курбанов Р.A.

\section{МЕЖДУНАРОДНОЕ РЕГИОНАЛЬНОЕ ПРАВО: ПОНЯТИЕ, ПРЕДМЕТ И СИСТЕМА}

Аннотация. В статье представлена авторская концепция формирования на нынешнем этапе развития общества международного регионального права как отрасли международного права. Система права постоянно пополняется новыми отраслями и подотраслями права, институтами и нормами, что в целом делает ее более эффективной. Изучение интеграционных процессов на евразийском пространстве в условиях развития геополитической конкуренции, активного формирования в мире новых региональных экономических, сочиальных и военно-политических пространств, требуют мобилизации не только политических, социальных, экономических, но и правовых ресурсов. Изучение и анализ региональной интеграции необходим с правовой позиции, поскольку в основе любого взаимодействия государств на межнациональном уровне, в том числе и в рамках региональных организачий, лежит право. Комплексный анализ интеграционных процессов в рамках существующих региональных образований позволил автору выявить ряд признаков, таких как слияние, взаимопроникновение государственных интересов, что обеспечивает баланс начиональных интересов государств - членов региональной организации, с одной стороны, и интересов самого регионального образования, с другой. Автором представленной статьи обосновывается вывод о том, что создание и функиионирование в современном мире таких региональных объединений невозможно без наличия собственно международного регионального права, элементы которого могут обладать определенной автономией в отношении как национального права государств-членов, так и международного права.

Ключевые слова: Региональная интеграчия, международное региональное право, система права, евразийское право, правовая система, систематизация, структуризация, принципь права, отрасль права, региональное право.

Abstract: This article presents an original concept of establishment of international regional law as a branch of international law at the present stage of social development. The legal system is constantly being updated with new branches and sub-branches of law, institutions, and norms, which makes it more efficient overall. The study of integrational processes within Eurasian territory in the conditions of development of geopolitical competitiveness, active formation of new regional economic, social, and military-political spaces, demands mobilization of not only political, social, and economic resources, but also legal. A complex analysis of integrational processes within the framework of current regional formations allowed the author to determine a number of signs such as fusion and interconnection of national interests, which ensures balance of national interests of the member-states of regional formation on one hand, and the interests of the regional formation itself on the other. The author substantiates the conclusion that creation and functionality of such regional formations is impossible without presence of 
international regional law, the element of which can possess certain level of autonomy with regards to both, national law of the member-states, as well as the international law.

Keywords: Principles of law, structuring, systematization, legal system, Eurasian Law, system of law, international regional law, regional integration, branch of law, regional law.

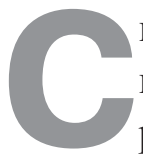

возникновением новых отношений, которые требуют соответствующей регламентации, система права постоянно пополняется новыми отраслями и подотраслями права, институтами и нормами, что в целом делает ее более эффективной.

Одним из таких вновь образованных составных элементов международного права уже является европейское право, которое стало одним из направлений развития юридической науки России. Юристы, рассматривая основную составную часть европейского права - право Европейского Союза, отмечают, что оно вобрало в себя «лучшие черты международного права и национального права наиболее развитых демократических государств Европы», имея при этом наднациональный характер[1]. Не ставя перед собой задачу подробного анализа становления европейского права как правового образования, науки и учебной дисциплины, отметим, что этот процесс занял достаточно длительное время.

Активно развиваются процессы на евразийском пространстве ${ }^{1}$, и в настоящее время

\footnotetext{
1 Понятие «евразийское пространство» использовано в целях определения политико-географических пределов сотрудничества евразийских стран. Множественность евразийских межгосударственных объединений, различное толкование понятия и географических пределов «евразийского пространства» (по крайней мере, наличие трех его значений - пространство Большой Евразии (в понимании географического континента)); «постсоветское пространство» и пространство «евразийского полюса» в современном понимании (территория, охватываемая функционированием, в том числе и таких организаций как БРИКС, ШОС) «размывает» ее «евразийские» географические пространствен-
}

одним из приоритетных направлений развития юридической науки России, несомненно, может стать евразийское право.

При этом в современных условиях необходимо учитывать тенденции по активному формированию международных региональных правовых комплексов не только в Европе и Евразии, но и в Америке, Африке, Азии и Океании.

Первоначальными шагами на пути к интеграции стран региона выступают прямые международные связи в различных областях: в сфере экономики, внешней политики, социальной сфере, военной сфере и т.д. Причем такие связи вначале формируются на уровне первичных субъектов, но в дальнейшем развиваются как «вглубь», так и «вширь», что в итоге ведет к взаимоприспособлению всех стран - участниц регионального объединения в соответствующих сферах общественной жизни. Интеграционные процессы в рамках учрежденных региональных образований характеризуются слиянием, взаимопроникновением государственных интересов, обеспечивая баланс национальных интересов государств - членов региональной организации, с одной стороны, и интересов самого регионального образования, с другой. При этом создание и функционирование таких региональных объединений невозможно без наличия собственно международного регионального

ные пределы. В этом смысле понятие «евразийское пространство» определяет в настоящей работе пространственные пределы, в частности, ЕАЭС, СНГ, ШОС, БРИКС и иных субрегиональных евразийских международных организаций (СГ и др.). 
nрава, элементы которого могут обладать определенной автономией в отношении как национального права государств-членов, так и международного права.

Предложенное название не случайно. В доктрине раннее уже высказывались мнения о процессах формирования «интеграционного права», «права региональной интеграции», а также позиции, в соответствии с которой в рамках международного права выделялось региональное международное право[2] или региональные международные правовые комплексы[3].

В настоящем исследовании намеренно используется термин «региональное» ${ }^{2}$, поскольку оно является ключевым в описании тех процессов, которые лежат в основе предмета международного регионального права, в свою очередь понятие «интеграциия» выступает в качестве отличительного признака всего процесса регионализации. О

${ }^{2}$ См: Капустин А.Я. Международно-правовые формы региональной экономической интеграции и международный правопорядок: концепции и подходы // Глобализация и интеграционные процессы в Азиатско-Тихоокеанском регионе (правовое и экономическое исследование): монография / Под ред. Т.Я. Хабриевой. - М.: Институт законодательства и сравнительного правоведения при Правительстве Российской Федерации: ИНФРА-М, 2014.: «... взаимодействие двух определяющих мировое развитие тенденций (регионализм и универсализм) пронизывает практически все основные отрасли международного публичного права, что неизбежно, поскольку государства в силу присущего им суверенитета свободны в выборе международно-правовых средств... Парадокс заключается в том, что предназначение регионализма - заниматься теми проблемами, которые не получили своего решения в универсальных международно-правовых актах, в том, как на практике это не мешает регионализму находить более эффективные решения международных проблем, чем это удается сделать на универсальном уровне (например, международно-правовое регулирование защиты прав человека на универсальном и региональном, например в рамках Совета Европы, уровнях). международных региональных соглашениях говорится и в ст. 52 Устава ООН: «Настоящий устав ни в коей мере не препятствует существованию региональных соглашений...»³. Устав ООН предусматривает создание региональных соглашений или органов для поддержания мира и безопасности в регионе при условии, что такие соглашения или органы и их деятельность совместимы с целями и принципами ООН. При этом региональное сотрудничество в иных областях Уставом не регламентируется [4].

Использование понятия «международное» в названии международного регионального права обусловлено двумя причинами: с одной стороны, по аналогии с названиями отраслей международного права, поскольку международное региональное право является составной частью международного права, с другой стороны, без указания на международный характер регионального права могут возникнуть ассоциации с «регионами» в рамках федеративных государств, к числу которых относится и Россия.

\footnotetext{
${ }^{3}$ Капустин А.Я. Ук. Соч. «Концепция международно-правового закрепления понятия регионализма складывалась постепенно. Статут Лиги Наций дал определение регионализма по аналогии. В статье 21 говорилось, что такие ограниченные пределами известных районов соглашения ... которые обеспечивают сохранение мира, не рассматриваются как несовместимые с каким-либо из постановлений настоящего Статута.... Статут четко не определил, какими именно средствами (принудительными или путем мирного урегулирования) такие соглашения будут обеспечивать сохранность мира, что открывало широкие возможности для толкований. ...При подготовке Устава ООН также велись споры относительно целесообразности включения в него положений о региональных организациях. Поскольку верх одержала позиция сторонников региональных организаций, в Устав ООН была включена гл. VIII «Региональные соглашения и органы».
} 


\section{Понятие и предмет международного} регионального права

Соотночение международной и национальной правовых систем

Необходимость установления места международного регионального права и отнесения его к системе международного или национального права обусловлена нахождением регионального права на стадии становления. В этой связи, прежде всего, целесообразно рассмотреть соотношение международной и национальной правовых систем.

Следует отметить, что все выдвинутые теории можно отнести к двум основным доктринальным подходам - монистическому и дуалистическому.

Суть монистического доктринального подхода заключается в идее, предложенной В. Кауфманном и получившей развитие в трудах Г. Кельзена [5] и его сторонников[6], о том, что в мире нет разных правовых систем (международного и национального права), есть только единая универсальная правовая система, а международное и национальное право являются ее составными частями. С определенной долей условности с этим можно было бы согласиться, если бы не утверждение представителей данного подхода о том, что международное и национальное право вообще не обладают никакой собственной самостоятельностью.

Таким образом, Г. Кельзен не усматривал различий между национальным и международным правом, за исключением способа их образования. Он считал, что у названных систем единый предмет правового регулирования, единый субъект (индивид), а также единая цель - недопущение вредного для общества поведения индивида (или их групп) и поощрение полезного поведения.

Подобный вывод ошибочен. Приведем мнение известного английского юриста
Л. Оппенгейма, который, критикуя данный подход, отметил, что монистическая доктрина неправомерно отрицает многие вполне очевидные доводы и положения, в частности, указывая на различный субъектный состав[7].

Советский юрист, известный ученый Г.И. Тункин характеризовал подход Г. Кельзена о «недопущении существования различных, но взаимосвязанных систем» как недиалектический[8].

В свою очередь, второй доктринальный подход к соотнесению международной и национальной правовых систем - доктрина дуализма - заключается в признании полной их самостоятельности.

Эта доктрина возникла в конце XIX - начале XX века. Её основатели исходили из того, что самостоятельность названных систем представляет собой объективное явление, которое обусловлено многими факторами, к числу которых, в частности, отнесен предмет регулирования. Более того, в литературе было высказано спорное категоричное мнение, в соответствии с которым ни один из рассматриваемых правопорядков не может создавать или изменять нормы другого. Использование международно-правовых норм в рамках национального (внутригосударственного) права любого государства зависит исключительно от усмотрения последнего. При этом, в случае использования международных норм в национальном праве, они не трансформируются в нормы национального права. В свою очередь, национальное право не применяется в международных отношениях[9].

Известный сторонник дуалистического доктринального подхода Х. Триппель в своем исследовании «Международное право и внутригосударственное право» 1899 г. проанализировал соотношение международного и национального права. При этом он расценивал 
данные области права как соприкасающиеся, но никогда не пересекающиеся, что находит проявление в «трансформации» норм одной правовой системы в нормы другой[10].

Аналогичную позицию отстаивает Л. Оппенгейм, который утверждает, что международное и национальное право государств существенно отличаются друг от друга[7].

Следует отметить, что дуалистический доктринальный подход к рассмотрению соотнесения международной и национальной правовых систем является доминирующим. По мнению Г.И. Тункина, международное право признается не только самостоятельной системой, но системой своеобразной, отличной от национальной правовой системы. Оно состоит из международного права, рекомендаций международных организаций и международных договоренностей[11].

Мнения о том, что международное право является правовой системой, придерживаются такие авторы, как С.С. Алексеев[12], Н.А. Ушаков[13], А.П. Мовчан[14], С.А. Гуреев[15], Г.И. Курдюков[16], Г.В. Игнатенко[17] и т.д.

Вместе с тем в отечественной доктрине высказывается также позиция, в соответствии с которой международное право рассматривается в качестве отрасли права[18]. Так, по мнению А.И. Полторака и Л.И. Савинского международное право следует считать обширной и сложной отраслью права, нормы которой регулируют единый комплекс качественно своеобразных общественных отношений[19].

\section{Доктрина о месте международного частного права}

Целесообразно указать на один из дискуссионных в доктрине подходов о месте международного частного права. По мне- нию некоторых ученых, международное частное право следует рассматривать в системе международного права. Как отмечает В.И. Маргиев, МЧП представляет собой самостоятельную отрасль системы международного права[20]. К.А Бекяшев утверждает о существовании в системе международного права (как правовой системы) двух основных самостоятельных отраслей права: международного публичного и международного частного права. Аналогичной позиции придерживается С.А. Малинин[21].

Вместе с тем в литературе была высказана позиция, в соответствии с которой МЧП является полисистемным комплексом, который возникает в результате взаимодействия определенных частей национально-правовых систем между собой и с определенной частью международного публичного права при регулировании международных отношений невластного характера. При этом такой комплекс не исключается из национальной системы права или международного публичного права и регулирует «особую группу общественных отношений, обладающих двойственным характером и не имеющих своей «собственной» системы права»[22].

Большинство же авторов, отстаивающих цивилистическую концепцию МЧП, справедливо указывают на его место в системе гражданского права, т.е. национального права[23]. Как отмечает И.И. Лукашук, международное частное право представляет собой отрасль права, которая регулирует гражданско-правовые отношения, имеющие международный характер. При этом автор прямо указывает на то, что международное частное право является составной частью национальной правовой системы, его нормы создаются государством самостоятельно[24]. 
Признавая наличие для международного и национального права ряда общих признаков (государственно-волевой характер, использование юридических норм в качестве регулятора общественных отношений, возможность принудительного обеспечения соблюдения норм права и др.), большинство ведущих специалистов в области международного права отмечают его существенные отличия, к числу которых, в частности, относятся предмет правового регулирования, субъекты и объекты права, источники права, способы образования норм права и способы принуждения субъектов права к соблюдению этих норм[25].

Несмотря на явное отличие национального и международного права, в отношении и международного, и национального права мы имеем дело с совокупностью нормативных правил, которые лежат в основе самой широкой системной конструкции - правовой системы. Исходя из такого понимания рассматриваемой правовой категории, необходимо поддержать представителей дуалистического доктринального подхода.

\section{Определение места международного регионального права}

Изложенные выше выводы представляют особый интерес с точки зрения определения места международного регионального права.

В процессе регионализации (при образовании региональной организации) создается определенное пространство, в пределах которого действуют единые собственные правовые нормы. Кроме того, посредством интеграции возникает определенная институционная система, которая призвана непосредственно управлять интеграционным процессом в том или ином регионе.
Учитывая соответствующие отношения на межгосударственном уровне, не вызывает сомнений необходимость включения такой системы взаимодействия стран в сферу действия международного права.

Ряд авторов на примере европейского права, с точки зрения его объема, предлагают рассматривать европейское право не в системе международного права, а в качестве самостоятельной правовой системы. Более того, как на отдельную правовую систему указывают на право Европейского союза[26].

C таким утверждением сложно согласиться. Несомненно, что в процессе взаимодействия государств в рамках регионального объединения могут создаваться нормы, которые имеют наднациональный характер, однако это не является основанием для выделения их в самостоятельные правовые системы. Наднациональность несомненно является отличительным признаком всех международных организаций, к числу которых относятся и международные региональные организации. Правовые акты, принимаемые в рамках региональных объединений, безусловно, не относятся к национальному праву, а распространяя свое действие на государства, носят международный характер. При достижении странами наивысшей стадии интеграции (федерации, конфедерации и т.д.) они трансформируются в национальное право и действуют как национальная правовая система. Поэтому в настоящее время нет оснований говорить о возможности формирования отдельной (наравне с международной и национальной) правовой системы.

Принимая во внимание специфику унификации международного регионального права, целесообразно проанализировать унификацию норм международного права и международного регионального права в сравнении. 
Во-первых, в основе международной унификации норм лежит международный правотворческий процесс (idem per idem ${ }^{4}$ ), который отличается значительной сложностью ввиду отсутствия единого законодательного органа. В то время как основой международного регионального права правотворческая деятельность, как правило, уполномоченных органов конкретного регионального объединения.

Второе различие - в способах унификации. Международно-правовая унификация основана на использовании традиционных методов: конвенционного метода и метода принятия типовых законов, что также характерно для ряда региональных организаций, в соответствии с документами которых принимаемые ими нормы носят рекомендательный характер. В свою очередь, для многих региональных объединений характерно принятие обязательных для исполнения норм.

Третье отличие - различная правовая природа унифицированных норм: чтобы нормы международного права являлись обязательными для исполнения каким-либо государством они, как правило, должны быть ратифицированы этим государством, а введение в действие норм международного регионального права в ряде случаев не требует ратификации и имплементации в национальное законодательство, такие нормы применяются напрямую.

Выбор правовой формы зависит от тех целей, ради которых государства объединяются, а также от воли субъекта, принимающего властное решение. Государства - члены региональной организации в соответствии с учредительным договором при-

\footnotetext{
4 Лат.: то же посредством того же; определение через
} определяемое. нимают общеобязательные решения с готовностью реализовать их.

Если в определенных сферах общественной жизни, по мнению государств членов регионального объединения, еще не сложились условия для интеграционных процессов, там продолжает действовать национальное право государств. В случае достижения согласия по определенным вопросам, они становятся предметом правового регулирования регионального объединения.

Международное региональное право не может рассматриваться как часть национальной системы права, во-первых, в силу специфики взаимоотношений государств на международном региональном уровне, что свойственно именно международному праву. Во-вторых, международное региональное право направлено на регламентацию тех вопросов, которые включаются в сферу интересов сотрудничающих стран, что относится к предмету международного права. В-третьих, нормы систем права региональных объединений отличаются от норм национального права. Как правило, региональные нормы могут иметь приоритет над национальным правом, т.е. обладать высшей силой по сравнению с нормами национальных законодательств государств членов регионального объединения.

Вместе с тем не вызывает сомнений возможность проникновения норм национального права в систему права регионального организации, что наиболее интенсивно происходит в экономической сфере. В основе большинства региональных объединений лежат экономические интересы стран-членов сообщества. Существуют региональные организации, для которых экономическая сфера взаимодействия является основной или даже единственной областью 
сотрудничества. Организации, занимающиеся, в первую очередь, экономической интеграцией, являются также основной движущей силой правовой гармонизации[27]. В универсальных региональных объединениях сотрудничество осуществляется во всех основных направлениях. В качестве примера таких региональных организаций следует назвать СНГ, Евросоюз, ОАГ, Лигу арабских государств и ряд иных.

\section{Понятие международного регионального права}

Для формулирования понятия международного регионального права необходимо проанализировать отношения, входящие в его предмет.

В общепринятом понимании под предметом права в отечественной теории рассматривают общественные отношения[28]. Как отмечает В.Ф. Яковлев применительно к установлению предмета гражданского права «определить предмет гражданского права значит установить круг регулируемых им общественных отношений, выявить сущность и характерные черты последних и тем самым обнаружить объективные основания данной отрасли»[29]. Кроме того, изучение предмета права должно осуществляться во взаимосвязи с самим правом, в противном случае за предмет права можно выдать то, что таковым в действительности не является.

В целях выявления специфики отношений, регулируемых международным региональным правом, целесообразно исследовать предмет международного права.

Традиционно международное право понимается как совокупность и система норм, которые направлены на регламентацию отношений между государствами и иными его субъектами[30].
В доктрине отношения, регулируемые нормами международного права, принято делить на две большие группы: межгосударственные и не- межгосударственные.

К межгосударственным отношениям относят отношения между государствами, которые составляют основу предмета международного права. Они возникают за пределами внутренней компетенции государств и их территорий, в различных областях общественной жизни, например, в области прав человека, в сфере охраны окружающей среды, в политической, экономической и иных сферах. Международные отношения между государствами основаны на равноправии государств и осуществляются посредством совместных органов, к числу которых относятся комиссии, комитеты, совещания и иные органы, а также посредством принятия совместных решений[31].

Как отмечает С.В. Черниченко, для международного права характерен координационный подход, который наглядно иллюстрирует процесс его создания - путем согласования волеизъявлений участниками межгосударственных отношений[32]. Такие отношения строятся по горизонтали, в них отсутствует жесткая система, нет единого властного органа, а также нет какого-либо подчинения. Для них характерно не просто равенство государств, но и взаимосотрудничество, партнерство.

Международное право регулирует не только межгосударственные, но и иные отношения, именуемые немежгосударственными. Таковы отношения, в которых государство либо выступает одним из участников, либо вообще не участвует. В данную группу включаются отношения между государствами и международными организациями, а также отношения между самими международными организациями. 
DOI: $10.7256 / 2226-6305.2015 .3 .16209$

При цитировании этой статьи сноска на dоі обязательна

Международное право и международные организации•з•2015

International Law and International Organizations

\section{Международное региональное право и право международных организаций}

С развитием на мировой арене процессов регионализации и глобализации, многие исследователи международного права стали выделять в качестве составной части международного права (отрасли права) право международных организаций[33]. «Право международных организаций - это отрасль международного права, включающая в себя принципы и нормы, регулирующие вопросы создания и функционирования международных организаций»[34].

На определенном временном этапе региональные отношения действительно могли «соответствовать» предмету права международных организаций. Однако в настоящее время, когда происходит углубление и развитие различных форм региональной интеграции, международное региональное право следует отграничить от права международных организаций, что в первую очередь, обусловлено отличительными чертами региональной организации от универсальной международной организации, их различным правовым статусом и спецификой осуществления ими своей деятельности (более подробно отличительные признаки международных универсальных и региональных организаций будут раскрыты далее). При этом следует исходить из того, что и международные организации и региональные объединения являются субъектами международного права.

Соответственно, право международных организаций и международное региональное право в системе международного права образуют отдельные самостоятельные подразделения.

Кроме того, за признание регионального международного права самостоятельным подразделением международного права гово- рит проводимая в целях устранения противоречий между национальным и региональным законодательством унификация и гармонизация национального законодательства стран членов региональных организаций.

\section{Предмет международного регионального права}

Предмет международного регионального права представляет собой достаточно сложную структуру отношений. Первый уровень отношений, входящих в предмет, составляют отношения государств по формированию (учреждению) регионального объединения и его ликвидации (роспуску).

Названную группу отношений, на первый взгляд, можно было бы отнести и к предмету права международных организаций, однако целесообразно включить ее в предмет правового регулирования международного регионального права по следующим основаниям.

Во-первых, такие отношения обладают определенной спецификой, отличной от отношений, составляющих предмет права международных организаций, в том числе и от отношений по созданию международной организации. Когда страны ведут переговоры относительно учреждения (создания) регионального объединения, они намерены решать общие проблемы опосредованно, через создаваемую региональную организацию, и их цели могут не совпадать, а порой противоречить интересам и целям других региональных структур.

Во-вторых, на мировом уровне функционирует более ста тридцати региональных объединений, которые различны по степени (глубине) интеграции, сферам взаимодействия стран в рамках каждой из них, по наличию или отсутствию постоянно действующих органов и по иным не менее принципи- 
альным вопросам, что требует относительно обособленного правового регулирования.

Вторую группу отношений, которая должна быть включена в предмет международного регионального права, составляют отношения уже созданных региональных объединений с государствами - его участниками.

Данная группа отношений не должна и не может входить в предмет права международных организаций. Такие отношения отличаются разнообразием внутри каждого конкретного регионального объединения и обладают присущей именно им спецификой с учетом норм, принимаемых на уровне регионального объединения, а также влиянием пограничных норм международного и национального права каждого члена определенной региональной структуры.

Эти отношения выходят «за рамки» предмета права международных организаций. По мнению К.А. Бекяшева, в предмет последнего включаются отношения, связанные с созданием и деятельностью международных организаций, а также взаимоотношения с иными субъектами международного права[25]. Вместе с тем Г.В. Игнатенко более широко рассматривает предмет права международных организаций. По его утверждению, нормы права международных организаций регламентируют статус межгосударственных организаций и объединений, их субъектный состав, структуру, полномочия и порядок деятельности органов, юридическую силу их актов[17].

Юридическая сила норм, принимаемых на региональном уровне, различна и определяется учредительными документами самого регионального объединения. По юридической силе нормы внутреннего права региональной организации можно разделить на:

1) акты региональных организаций, которые имеют обязательную силу для испол- нения их членами без соответствующей ратификации;

2) акты региональных организаций, которые обязательны для исполнения их членами только после совершения необходимых действий со стороны последних (подписания, ратификации и т.п.);

3) рекомендательные акты региональных организаций, которые не подлежат ратификации и не обязательны для исполнения государствами - участниками региональных объединений. Такие акты определяют позицию региональной организации в отношении поведения их участников и во многом влияют на проведение их внутренней политики, Очевидно, что эти акты обладают наименьшей юридической силой и их применение на практике может вызывать определенные сложности.

Таким образом, нормы международных организаций носят, как правило, рекомендательный характер, в то время как в рамках региональных организаций, помимо рекомендательных актов, может в большей мере наблюдаться наличие как актов, имеющих обязательную силу без соответствующей ратификации, так и актов, обязательных для исполнения после совершения необходимых действий (подписания, ратификации и т.п.).

При этом независимо от того, носят ли акты региональных организаций обязательный или рекомендательный характер, отношения всех созданных региональных интеграционных объединений с государствами - их членами необходимо относить к группе отношений, регулируемых международным региональным правом.

Третья группа отношений, которая может быть включена в предмет международного регионального права, - это отношения стран-членов регионального объединения между собой в предусмотренных учреди- 
тельными документами сферах взаимодействия (экономической, социальной, военно-политической, правовой), регулируемые как частными, так и публичными отраслями и институтами. Отношения этих же стран между собой в иных сферах общественной жизни (сотрудничество в сферах, не предусмотренное в рамках региональных объединений) должны регулироваться иными отраслями международного права. Данная группа отношений существенно отличает предмет регионального международного права от предмета права международных организаций, которое, в первую очередь, рассматривает институциональные основы международных организаций.

Такие отношения (взаимоотношения стран-членов регионального объединения между собой) нуждаются в самостоятельной регламентации (в рамках международного регионального права), поскольку межгосударственные отношения тех сторон, которые являются участниками (членами) одного регионального объединения, могут быть осложнены собственными нормами регионального объединения, а также правилами двух - и многосторонних соглашений, которые заключаются в рамках регионального объединения для достижения поставленных перед сторонами целей.

К четвертой группе отношений, регулируемых международным региональным правом, необходимо отнести взаимоотношения институциональных структур в рамках конкретного регионального объединения.

Таким образом, отношения, регулируемые международным региональным правом, образуют четыре самостоятельные группы, которые обладают определенной спецификой и позволяют выделить региональное международное право в отдельный структурный элемент международного права.
На основании изложенного можно сделать вывод о том, что международное региональное право - это отрасль международного права, регулирующая комплекс общественных отношений государств по созданию и ликвидации региональных организаций, взаимодействию региональных организаций с их членами, по сотрудничеству государств между собой в рамках созданных ими региональных организаций в различных сферах отношений, обусловленных целями региональных организаций, а также взаимодействию региональных институциональных структур в рамках конкретного объединения.

\section{Субъекты международного регионального права}

Одним из проблемных в международном региональном праве является вопрос определения его субъектов и их отграничения от субъектов права международных организаций.

Современные международные отношения преимущественно продолжают регламентировать отношения между государствами, при этом активными участниками международного права стали международные организации.

В связи с этим особое значение приобретает вопрос выявления отличительных признаков международных региональных организаций от универсальных международных организаций, для чего целесообразно исследовать доктринальные признаки международной организации.

В доктрине международного права выделяют ряд признаков международных организаций. Одним из главных признаков международной организации, который, по мнению Н.Ю. Ерпылевой и Д.М. Максимова[35], отличает их от иных правовых форм международного взаимодействия, является наличие 
у них постоянно действующего внутриорганизационного механизма. Последний, в частности, понимается как «система различного рода органов, созданных в соответствии с учредительным и другими актами международной организации, находящихся в постоянном взаимодействии на основе принципов и норм международного права»[36].

Данный признак (наличие внутренней организационной структуры) в большей степени присущ региональным организациям, более того именно последние могут обладать наиболее сложной и при этом развитой институализацией. В качестве примера можно привести структуру Евросоюза, который до вступления в силу Лиссабонского договора имел довольно сложную структуру (два европейских сообщества).

Следующий признак международных организаций - их создание в соответствии с международным правом. Если международная организация была учреждена с нарушением норм международного права или ее деятельность противоречит международному праву, учредительные документы такой организации могут быть признаны недействительными.

При создании региональных организаций должны быть соблюдены общие нормы международного права, а также его основные принципы. Несомненно, что цели деятельности региональных организаций не должны нарушать, в первую очередь, права и интересы всего человечества, т.е. общие принципы международного права. Таким образом, данный признак присущ также региональным организациям.

В качестве третьего признака международных организаций принято называть их учреждение на основе международного договора. В качестве разновидностей учредительного договора используются соглашения, конвенции, протоколы, трактаты и т.д.
Сторонами международного договора являются, как правило, государства. Однако все чаще универсальные международные организации в отличие от региональных создаются в соответствии с резолюциями иных международных организаций.

При этом сторонами учредительных актов региональных организаций могут выступать государства, специализированные организации ООН и региональные финансовые институты (Азиатский банк развития и т.д.). Кроме того, международные региональные объединения также могут функционировать в рамках консультативного формата (в виде саммитов, форумов, программ на уровне глав государств, правительств и т.д.), при этом в последнее время наблюдается как увеличение их числа, так и расширение сферы взаимодействия 5 .

Одним из признаков международной организации является взаимодействие стран в определенных сферах общественной жизни. Другими словами, международные организации создаются в целях координации такого сотрудничества в той или иной сфеpe: политической, военной, трудовой сфере и т.д. Вместе с тем существуют так называемые универсальные международные организации. Несомненно, что данный признак является существенным и для региональ-

\footnotetext{
${ }^{5}$ Г.М. Вельяминов относит к неформальным международным объединениям формирования, которые он определяет с 1977 г. (см. Международные экономические организации социалистических стран. Бюллетень иностранной коммерческой информации. М.Изд. Научно-исследовательского института Минвнешторга СССР, 1977.C-20-23.) в качестве параорганизаций. Параорганизации могут быть межправительственными и неправительственными, быть схожи с международными организациями, но они принципиально отличны от них тем, что юридически не наделяются правосубъектностью. См.: Вельяминов Г.М. Международное право: опыты. М., 2015. С. 507-508.
} 
ных организаций, поскольку каждая из них создается государствами - ее членами ради достижения заранее определенных целей, которые по мере развития интеграционных связей претерпевают изменения и дополнения, при этом такие цели определены, как уже отмечалось в учредительных документах региональной организации.

Наличие прав и обязанностей как признак международных организаций закреплен в их учредительных документах. Более того, в ряде случаев учредительными актами могут быть указаны пределы правоспособности международных организаций. В частности, ст. 3 (5«С») Устава МАГАТЭ прямо запрещает Агентству при выполнении своих функций, связанных с предоставлением помощи своим членам, руководствоваться политическими, экономическими, военными или иными требованиями, несовместимыми с положениями Устава этой организации[37]. Права и обязанности региональных организаций определяются аналогичным образом.

Исходя из рассмотренных признаков международных организаций, можно сделать вывод о том, что они присущи и региональным организациям. Необходимо, однако, разделять данных субъектов международного права, поскольку каждая региональная организация является международной, но не каждая международная организация является региональной.

В качестве отличительных признаков региональных организаций следует использовать признак территориальности и целей деятельности. При этом признак территориальности в данном случае имеет трансграничное значение. Цели региональных организаций обусловлены причинами интеграционных процессов в регионе, проблемами, стоящими перед странами того или иного региона, вызовами мировых региональных интеграционных процессов (т.е. глобализацией) и иными обстоятельствами. В свою очередь, международные организации призваны координировать сотрудничество стран на мировом уровне в общечеловеческих целях.

\section{Методы правового регулирования}

Метод правового регулирования является одним из тех критериев, которые большинство ученых используют для определения места совокупности норм права в отраслевой системе права.

Выделяют два метода правового регулирования: императивный метод (метод субординации) и метод диспозитивного регулирования (метод координации). Первый метод часто именуют методом подчинения или методом властных предписаний. Второй метод правового регулирования - диспозитивный метод - используется при равном положении участников общественных отношений.

В юридической науке спорен вопрос о том, должен ли быть в отрасли права один или несколько методов правового регулирования. Например, В.В. Лаптев доказывал, что в сложных отраслях права, в том числе в предпринимательском праве, используются несколько различных методов правового регулирования, и в то же время признавал предпринимательское право самостоятельной отраслью права[38].

Помимо названных методов правового регулирования в юридической литературе выделяют также такие методы, как метод автономии, метод поощрения, метод рекомендаций и иные[39].

Достаточно часто в литературе встречаются более расширенные определения ме- 
тода правового регулирования, когда в данное понятие включаются также сами средства правового воздействия, совокупность которых составляет механизм правового регулирования[40]. В таком случае метод характеризуется не столько через правовое положение субъектов правоотношений по отношению друг к другу, сколько через особенности возникающих между ними отношений, через специфику разрешения конфликтных ситуаций.

Значение метода правового регулирования в решении вопроса об отнесении определенной совокупности правовых положений к отраслевому делению права национальной системы нельзя как недооценивать, так и переоценивать. Достаточно сложно, признавая всего два основных метода правового регулирования и считая остальные методы производными от диспозитивного и императивного методов, выделить ту их комбинацию, которая позволила бы объединить те или иные отношения в предмет самостоятельной отрасли права.

Вместе с тем отрицание того факта, что каждая отрасль права отличается методом правового регулирования может привести к отрыву правовой формы от содержания общественных отношений. В этом вопросе необходимо исходить из утверждения о том, что законодатель избирает ту или иную форму правового воздействия на субъектов конкретных отношений с учетом специфики этих отношений.

Метод является необходимым критерием, влияющим на определение места совокупности правовых норм (в данном случае норм регионального права) в системе права, однако он имеет второстепенное значение, поскольку основным критерием должен выступать предмет правового регулирования.

\section{Специфика публично-правового регулирования в международном праве}

В доктрине нет единого мнения относительно методов правового регулирования, используемых в международном праве. Например, Ю.А. Тихомиров считает, что преобладающими в методе публичного права (к которому, без сомнения, относится и международное право) являются средства - требования (обязывания и запреты), а также средства - ограничения, применение которых не зависит от воли субъектов международного права[41]. Другими словами, по его мнению, для публичных отношений характерен императивный метод правового регулирования, когда властный субъект устанавливает правила поведения в одностороннем обязывающем порядке.

Критикуя эту позицию, Н.Е. Тюрина отмечает, что такие характеристики в большей степени применимы к национальному публичному праву, но большей частью неприменимы к методу международного права[42]. Действительно, императивность в большей степени присуща национальному праву, а метод правового регулирования в международном праве нельзя считать в чистом виде императивным, поскольку ему на равных началах присуща и диспозитивность.

В свою очередь, властность, о которой говорила Н.Е. Тюрина, в международном праве скорее означает не верховенство кого-то из субъектов, а их взаимодействие, основанное на равных началах. При этом императивность, которая присуща международному праву, не носит всеобъемлющего характера.

В теории международного права высказана позиция, в соответствии с которой в международном праве доминирует координационный метод правового регулирования, который предполагает равенство сторон, от- 
сутствие какой-либо власти над субъектами международного права, а также согласованность нормативных предписаний[42].

В международном публичном праве, несомненно, имеет место публично-правовое регулирование, которое отличается определенной спецификой. Применение императивного метода, который в большей степени характерен для публичного права, в современном международном праве противоречит сущности последнего. Отношения между государствами должны строиться на началах равенства, а не на началах власти и подчинения. Таким образом, специфика публично-правового регулирования в международном (публичном) праве заключается в том, что публично-правовой аспект может иметь место и тогда, когда отношения между субъектами строятся на началах равенства.

По мнению ряда авторов, в международных отношениях все же имеет место централизованное воздействие на межгосударственные отношения[43]. Во-первых, такое воздействие выражается в нормах «jus cogens» ${ }^{6}$, которые обязательны для любого субъекта международных отношений, причем независимо от того, участвовал ли сам субъект в создании таких норм. Во-вторых, централизация выражается в обязательности решений Совета безопасности ООН.

Централизация в большей степени присуща методу международного регионального права, нежели другим отраслям международного права, поскольку именно в рамках региональных интеграционных объединений интенсивнее осуществляется правовое воздействие на членов региональных организаций. Это можно объяснить особой природой норм региональных объединений, которым могут быть присущи более строгие струк-

\footnotetext{
${ }^{6}$ Лат.: неоспоримое право
}

турированные институты, акты и нормы, а также тем, что управление деятельностью в соответствии с целями регионального объединения осуществляется из единого центра оно исходит от высших органов управления регионального объединения.

Наднациональный характер, присущий, по мнению некоторых авторов[44], международному праву, по своей сути более сходен с методом публичного права в национальных правовых системах. Не оспаривая такого утверждения, тем не менее необходимо отметить, что наднациональный характер присущ и методу международного регионального права, поскольку государства - члены при создании региональной организации могут наделять ее органы определенными полномочиями.

Таким образом, основу метода международного регионального права составляет добровольно согласованное решение о передаче определенных полномочий органам региональной организации.

Изложенное позволяет сделать следующие выводы.

Во-первых, международному региональному праву присущи используемые в международном и национальном праве основные методы (диспозитивный и императивный).

Во-вторых, специфика методов международного регионального права заключается в том, что его методам в большей степени, чем в международном праве может быть присуща централизация, что обусловлено спецификой взаимодействия государств в рамках регионального объединения.

В-третьих, на правообразование, а соответственно, и на выбор приоритетного метода правового регулирования (их совокупности) в рамках каждого отдельного регионального объединения влияет несколько факторов. К их числу следует отнести, в первую очередь, 
специфику отношений, регулируемых международным региональным правом.

В частности, в отношениях государств по созданию регионального объединения приоритетным выступает диспозитивный метод регулирования, предполагающий равенство сторон. Выбор же основного метода правового регулирования отношений между региональным объединением и его членами зависит от полномочий структурных органов региональной организации, т.е. решение этого вопроса производно и зависит от самих членов регионального объединения.

Государства могут наделить такие органы властными полномочиями, при этом исполнение принятых ими решений обязательно для стран - членов регионального объединения или же такие решения могут носить рекомендательный характер. В свою очередь, отношениям между членами конкретного регионального объединения в равной степени присущи оба метода правового регулирования, поскольку такие отношения основаны на равенстве стран, однако могут быть осложнены нормами региональной организации.

\section{Источники международного регионального права}

Нормы права должны быть зафиксированы в каком-либо правовом источнике, которым принято считать форму выражения правил поведения субъектов права.

В целях выявления специфики источников международного регионального права целесообразно исследовать их в сравнении с источниками международного права.

Действующие правовые акты не содержат исчерпывающего перечня источников международного права. Вместе с тем ученые[17], считая этот перечень исчерпывающим, ссылаются в подтверждение этого на ст. 38 Ста- тута Международного Суда ООН[45], которая в качестве основных источников международного права называет международный договор и международный обычай. От международного обычая следует отличать международные обыкновения, под которыми понимаются правила, применяемые государствами в их взаимоотношениях, но не имеющие обязательной юридической силы. К таким правилам относят, в частности, правила дипломатического этикета и дипломатического протокола, правила морского церемониала и т.д.

Такие источники международного права, как обычай и обыкновение могут являться также источниками международного регионального права и использоваться (применяться) в рамках сотрудничества стран конкретного регионального объединения, если иное не предусмотрено учредительными документами и иными актами региональной организации.

Что касается международного договоpa, то названный источник международного права активно используется и в международном региональном праве. На практике региональные объединения, как правило, создаются посредством заключения двустороннего (многостороннего) договора об их учреждении (Договор, учреждающий Европейское сообщество 1957 года; Договор об учреждении Восточноафриканского сообщества от 30 ноября 1999 года; Договор о гармонизации предпринимательского права в Африке от 17 октября 1993 года; Договор о создании Союзного государства Беларуси и России от 8 декабря 1999 года и т.д.).

Учредительные акты региональных объединений могут именоваться по-разному. На суть (правовую природу) такого акта его наименование не влияет. В этой связи можно привести следующие примеры: Соглашение 
об учреждении Организации технического и экономического сотрудничества стран Бенгальского залива от 6 июня 1997 года, Соглашение о создании Содружества Независимых Государств от 8 декабря 1991 года, Соглашение об учреждении Межправительственной организации по окружающей среде южной части Тихого океана от 16 июня 1993 года и т.д. Основные документы, на основе которых функционирует региональное образование, могут именоваться иначе: учредительный акт (Африканский союз), Алматинский акт (Совещание по взаимодействию и мерам доверия в Азии) и т.д.

В ст. 38 Статута Международного суда $\mathrm{OOH}$ в качестве источников права названы также общие принципы права, которые признаны цивилизованными нациями. Суд при вынесении решения должен руководствоваться также судебными решениями и доктринами квалифицированных специалистов по международному праву различных наций. Однако такие источники могут быть использованы исключительно как вспомогательные средства для определения правовых норм. Исходя из такого правила Статута можно сделать вывод о том, что такие вспомогательные средства относятся к источникам права.

В рамках международного регионального права следует выделить такую разновидность международного договора, как неформальный международный договор. Суть такого договора заключается в том, что стороны в регионе подписывают договор, текст которого ими разработан, однако государства ему не придали юридической силы международного договора, но при этом стороны исходят из необходимости соблюдения всех его положений в рамках их взаимоотношений. В международном региональном праве неформальный договор достаточно часто встречается в процессе учреждения регионального объединения, когда несколько стран договорились образовать региональную организацию для достижения конкретных целей, объявили об этом в согласованном акте (решении об учреждении регионального объединения), однако создание учредительного акта такой организации и придание ему юридической силы осуществляется гораздо позднее.

Например, впервые идея создания федерации трех территорий - Кении, Уганды и Танзании - возникла на конференциях Панафриканского движения стран Центральной, Восточной и Южной Африки (ПАФМЕКСА), проводимой в 1961-1962 годах. Основой такой федерации должна была послужить уже действующая на том этапе Организация общих служб Восточной Африки.

В соответствии с данным проектом интеграция в Восточной Африке должна была начаться сразу же после достижения этими тремя странами независимости. Упор при этом был направлен на политическую и экономическую сферы. В результате трехсторонний союз Кении, Танзании и Уганды - Восточноафриканское экономическое сообщество (предшественник современного Восточноафриканского сообщества - ВАС) - было образовано только 6 июня 1967 года7

Вместе с тем, учитывая специфику предмета международного регионального права и исходя из понимания его как отрасли международного права, необходимо иметь в виду, что источники международного регионального права, в первую очередь, подразделяются на источники первичного права регионального объединения и на источники вторичного (производного) права. При этом деление правовых актов на первичные и вто-

\footnotetext{
${ }^{7}$ Субрегиональная организация экономического и социального сотрудничества, создана в 1967 г., штаб квартира в г. Аруша (Танзания), население около 150 млн. чел., общая площадь 1,8 млн. кв. м.
} 
ричные устанавливает не только классификацию норм, но и основание для иерархии их взаимоотношений.

Первичное право международного регионального объединения составляют документы, носящие основополагающий характер. В первую очередь, к источникам первичного права следует отнести учредительные документы (договоры), в соответствии с которыми региональные организации действуют.

Кроме учредительных документов к первичным источникам регионального права относятся источники, которые содержат дополнения и изменения к ним (источники так называемого дополнительного первичного права). К таким документам относятся, прежде всего, так называемые ревизионные договоры, посредством которых вносятся поправки в учредительные документы, а также в ряде случаев договоры о присоединении (о вступлении в региональное объединение) новых государств. Последние заключаются, как правило, с согласия регионального объединения всеми государствами - его участниками, с одной стороны, и соответственно, вступающим в данное объединение государством, с другой.

Кроме того, составной частью такого рода договоров в ряде случаев может является акт (соглашение) об условиях присоединения, которым устанавливается переходный период для вновь присоединившегося государства в целях адаптации к требованиям регионального объединения. Таким актом (соглашением) вносятся также изменения в учредительные документы самого регионального объединения (как правило, в части состава участников региональной структуры).

Зачастую к таким актам (соглашениям) прилагаются многочисленные протоколы (они могут устанавливать особые изменения или дополнения к правовому статусу всту- пающих в региональное объединение государств), которые также являются их составной частью. Примерами таких протоколов в качестве их приложения к актам присоединения можно назвать ряд протоколов вступающих в ЕС государств: Протокол «О Фарерских островах», приложенный к Акту об условиях присоединения Великобритании, Ирландии и Дании 1972 года и т.д.

К источникам вторичного регионального права относятся правовые акты, которые принимаются уполномоченными органами регионального объединения в одностороннем порядке. Процедуры принятия такого рода правовых актов регламентированы нормами первичного права и не единообразны в различных региональных объединениях.

В частности, в ЕС применяются различные способы голосования: как единогласно, так и квалифицированным большинством, причем каждое государство-член ЕС имеет зафиксированное в договоре число голосов. Однако принципу «большинства голосов» отдается большее предпочтение, что значительно упрощает принятие решений по тем или иным вопросам.

Иная ситуация была предусмотрена в Договоре стран СНГ «О создании экономического союза», в соответствии с которым решения уполномоченных органов СНГ, которыми выступают Совет глав государств и Совет глав правительств, по вопросам функционирования экономического союза принимаются с общего согласия, т.е. консенсусом. При этом если государство-член СНГ заявляет о своей незаинтересованности в каком-либо вопросе, это не должно рассматриваться как препятствие для принятия решения.

Для некоторых региональных объединений характерен комбинированный порядок голосования. Например, в одной из крупнейших региональных организа- 
ций - Африканском союзе - решения Исполнительного совета принимаются на основе консенсуса или $2 / 3$ голосами государств-членов. При этом решения по процессуальным вопросам принимаются простым большинством голосов.

Для актов вторичного права характерно вступление их в силу без последующей ратификации или принятия со стороны государств - членов. Поэтому можно говорить о том, что такие акты носят скорее законодательный, чем договорный характер.

В сравнении с первичным правом, вторичное региональное право имеет гораздо больше материальных источников, что обусловлено характером деятельности региональных объединений, направленной на достижение поставленных целей ${ }^{8}$. Институты региональных интеграционных структур через реализацию своих полномочий издают акты вторичного права, производные от первичных, поскольку деятельность уполномоченных региональных органов ограничена пределами их компетенции.

В связи с этим акты первичного регионального права имеют приоритет перед вторичными актами и, соответственно, в системе норм международного регионального права обладают более высокой юридической силой по сравнению с последними.

Вместе с тем, несмотря на приоритет первичного права над нормами вторичного права, последние в правовой системе международного регионального права более «динамичны», поскольку именно посредством принятия актов вторичного права региональные

\footnotetext{
${ }^{8}$ В данном случае речь идет о нормах, издаваемых региональными объединениями, направленных на достижение поставленных учредительных целей. Материальных норм во вторичном праве больше, чем процессуальных (организационных), которые характерны для первичного права)
}

организации осуществляют регулирование отношений по всем вопросам, отнесенным к компетенции их органов.

Вторичное право, как и первичное, имеет свою структуру. Первую ее часть составляют правовые акты институтов регионального объединения. Такие акты могут носить как обязательный, так и рекомендательный характер. При этом доктрина и правоприменительная практика государств, в целях придания тому или иному акту обязательного или рекомендательного характера исходят из следующего. Юридически обязательный характер решения региональных органов регионального объединения имеют только в том случае, если это предусмотрено в международном договоре - учредительном акте организации или договоре, который заключается в его развитие (при его наличии).

При отсутствии специального указания на обязательный характер того или иного акта последний носит рекомендательный характер, и как следствие, не налагает на государство правовых обязательств. Такие акты служат формой для выдвижения предполагаемой, рекомендуемой модели поведения, определенным пожеланием в адрес государств-участников регионального объединения, а также иных физических и юридических лиц.

\section{Международные модельные нормы как инструмент унификации и гармонизации}

В качестве одного из перспективных направлений унификации и гармонизации национальных правовых систем многие региональные организации стали использовать такой специфический способ, как международные модельные нормы. 
Под модельными нормами принято понимать нормы, управомачивающие или обязывающие государства или других субъектов разработать и принять правовые акты или нормы (международные или внутригосударственные) определенного содержания.

В этой связи показателен пример правовой системы СНГ. Например, на основании Модельного гражданского кодекса СНГ были приняты ГК Узбекистана, части первые гражданских кодексов РФ, Казахстана, Кыргызской Республики. Разработчики этих кодексов постарались максимально отразить в них нормы Модельного ГК. Кроме того, на его основе подготовлены гражданские кодексы Беларуси, Армении, Молдовы, Украины (несмотря на структурные особенности ГК Украины).

К 2014 году Межпарламентская Ассамблея разработала более 328 документов, в том числе о внесение изменений в ранее принятые модельные, которые активно используются в работе парламентов всех государств-участников СНГ. Однако по одному и тому же модельному закону в силу рекомендательного характера таких норм в различных государствах СНГ могут быть приняты разные решения в зависимости от состояния национального законодательства и иных факторов.

В Латинской Америке на различных исторических этапах были разрабатаны проекты различных модельных законов, например, в 1963 году Межамериканской ассоциацией прокуратуры был подготовлен проект типового закона о прокуратуре, в 1956 году Межамериканским советом юристов был разработан проект единообразного закона об арбитраже, также были составлены проекты Модельного налогового кодекса для Латинской Америки, Типового латиноамериканского уголовного кодекса;
Латиноамериканского авиационного кодекса, Гражданского процессуального модельного кодекса для Ибероамерики.

Однако данные проекты модельных законов в большей части так и остались проектами, а зафиксированные в них принципы использовались в качестве «руководящих линий», действующие как обыкновения в целях регулирования тех или иных отношений. Так можно отметить следующие тенденции правовой гармонизации в государствах Латинской Америки:

1) преимущественная унификация норм, регулирующих правовой статус физических лиц. Что касается отношений предпринимательского характера, то их унификация не получила за несколькими исключениями такого развития;

2) стремление к подчинению как можно большего спектра общественных отношений национальному праву является основным направлением правовой гармонизации;

3 ) отсутствие ратификации государствами Латинской Америки принятых ими же международных договоров, в этой связи существенное практическое значение приобретают проблемы юридической силы нератифицированных международных договоров[46].

\section{Нормативные договоры как часть вторичного (производного) права}

Другую часть вторичного (производного) права составляют нормативные договоры, которые в зависимости от их субъектного состава подразделяются на два вида.

1. Дополнительные конвенции между государствами - членами одного регионального объединения. Если в отношении ряда вопросов региональные органы не были уполномочены издавать нормативные акты, то госу- 
дарства - члены регионального объединения могут между собой заключать соответствующие дополнительные конвенции.

Наиболее известными из таких актов являются Конвенция от 19 июня 1980 года «О праве, применимом к договорным обязательствам», Конвенция от 25 июля 1995 года «О создании Европейского полицейского ведомства (Конвенция о Европоле)», Конвенция от 26 июля 1995 года «О защите финансовых интересов Европейских сообществ», Конвенция от 29 мая 2000 года «О взаимной правовой помощи по уголовным делам между государствами-членами Европейского союза», a также Шенгенские соглашения, которые первоначально не входили в правовую систему Европейского союза.

Среди соответствующих актов в рамках СНГ можно назвать Конвенцию Содружества Независимых Государств о правах и основных свободах человека от 26 мая 1995 года, Конвенцию о правовой помощи и правовых отношениях по гражданским, семейным и уголовным делам от 7 октября 2002 года и т.д. Заключение таких конвенций между государствами - участниками региональных объединений постепенно вытесняется заключением нормативных актов региональных структур.

2. Межинституционные соглашения. Такие соглашения представляют собой нормативные акты, которые заключаются между институтами регионального объединения. Основная цель таких соглашений состоит в уточнении или дополнении отдельных положений учредительных документов (как правило, посредством таких актов вносятся изменения и дополнения в процедурные нормы правовой системы региональной структуры). Такие инструменты активно применяются в праве Европейского сообщества: как правило, они носят трехсторонний характер и заключаются от имени трех поли- тических институтов - Европейского парламента, Совета и Комиссии. Примером такого соглашения может служить Межинституционное соглашение от 16 декабря 2003 года «О повышении качества законотворческой деятельности».

\section{Решения международных региональных судов как особая группа источников права}

В свое время на этапе становления ЕС в его правовой системе наряду с первичным и вторичным правом появилась еще одна особая группа источников, которая состоит из решений региональных судов. Совокупность таких решений в различных правовых системах именуется по-разному: в странах англосаксонской системы (США, Англия, Ирландия и т.д.) - «прецедентное право», в странах континентальной системы права (Германия, Россия и т.д.) - «судебная практика».

Суть таких источников права заключается в толковании судом положений учредительных документов, а также иных как первичных, так и вторичных источников правовой системы регионального объединения. Более того, в ходе такого официального толкования суды в большинстве случаев выводят из смысла действующих правоположений новые принципы и нормы.

Однако не все региональные организации имеют в своей структуре постоянно действующие суды. В частности, создатели МЕРКОСУР изначально стремились не допустить создания независимого от государства судебного органа, в связи с чем в системе названного объединения предусмотрены исключительно арбитражные органы «ad hoc», которые не могут рассматриваться как постоянно действующие суды, предназначенные для развития права МЕРКОСУР, но действующие в соответствии с ним. 
Многие ученые отмечают важность создания в судебной системе постоянного ревизионного суда (Постоянный ревизионный суд МЕРКОСУР действует на основании Протокола Оливос 2002 г.) [47], однако этот судебный орган также не обладает преюдициальными полномочиями, в соответствии с чем он не вправе, как например Суд Европейского Союза, влиять на развитие национального права государств-членов.

\section{Принципы международного регионального права}

В целях выявления отраслевых принципов международного регионального права перечислим общие доктринальные принцииь международного права, основанные на таких универсальных актах, как Устав ООН от 26 июня 1945 года, Декларация о принципах международного права, касающихся дружественных отношений и сотрудничества между государствами в соответствии с Уставом ООН 1970 года, а также Заключительный акт СБСЕ 1975 года:

1) принцип суверенного равенства государств;

2) принцип невмешательства во внутренние дела;

3) принцип равноправия и самоопределения народов;

4) принцип неприменения силы или угрозы силы;

5) принцип мирного урегулирования споров;

6) принцип нерушимости границ;

7) принцип территориальной целостности государств;

8) принцип уважения прав человека и основных свобод;

9) принцип сотрудничества государств;

10) принцип добросовестного выполнения международных обязательств.

В отечественной судебной практике их применение вызывает затруднения. Так, ру- ководствуясь принципами международного права, суды в ряде случаев, к сожалению, не ссылаются на конкретные нормы или акты, ограничиваясь абстрактной ссылкой на «международно-правовые акты», «общепризнанные нормы», «нормы международного права» и т.д. Например, в Определении Судебной коллегии по гражданским делам Верховного Суда РФ от 1 февраля 2008 года № 80-В07-21[48] дана безадресная ссылка на «общепризнанные принципы и международные нормы». По всей вероятности суд счел, что все международные принципы применимы во всех случаях. В Особом мнении судьи Конституционного Суда РФ к Постановлению от 25 апреля 2001 году № 6-П о проверке конституционности ст. 265 УК РФ[49] также содержится ссылка на общепризнанные принципы и нормы международного права, которые признают достоинство личности как основу свободы. При этом непонятно, какие принципы имелись в виду и каков их источник.

Отсутствие в правоприменительной практике единообразия в использовании международных принципов позволяет сделать вывод о том, что вопрос об их применении имеет существенное значение. В доктрине неоднократно подчеркивалась необходимость разработки и принятия единого перечня общепринятых норм и принципов, которые существуют, в том числе в виде обычаев[50]. В Рекомендациях о применении общепризнанных принципов и норм международного права и международных договоров Российской Федерации, принятых на Всероссийском совещании в Москве 24 декабря 2002 года[51], было предложено опубликовать систематизированное собрание правовых позиций Конституционного Суда РФ, отражающих соответствующие принципы и нормы. Данная позиция поддержана и в научной литературе[52]. 
Попытки систематизации общепринятых принципов и норм международного права сделаны высшими судебными инстанциями. Пленум Верховного Суда РФ принял два Постановления от 31 октября 1995 г. № 8 [53] и от 10 октября 2003 г. № 5 [54]. При этом в Постановлении Пленума Верховного Суда РФ от 10 октября 2003 года № 5 в редакции от 5 марта 2013 года были даны разъяснения, что следует понимать под общепризнанными принципами международного права, а также указано, что их содержание раскрывается, в частности, в документах ОНН и ее специализированных учреждений.

В основе региональных интеграционных процессов, как и любых иных процессов, протекающих в различных сферах общественной жизни (политической, социальной, экономической и т.д.), также лежат определенные правила, которые признаются таковыми в силу устойчивого их повторения в различных процессах. Международное региональное право также построено на системе принципов, в основе которых лежат общие принципы международного права, а некоторые принципы имеют оригинальную природу.

Общие принципы международного права могут быть закреплены непосредственно в документах регионального объединения. Например, в 1990-е годы в Договор о Европейском союзе был включен ряд основополагающих правовых принципов: принципы свободы, демократии, уважения прав человека и основных свобод и принцип правового государства. На основании ст. 7 данного договора в случае их существенного и устойчивого нарушения государство может быть привлечено к ответственности в виде лишения отдельных прав, вытекающих из членства в Европейском союзе.
В ст. 3 Устава СНГ содержится следующий перечень принципов: уважение суверенитета государств - членов, нерушимость государственных границ, признание существующих границ, территориальная целостность государств, верховенство международного права в межгосударственных отношениях, невмешательство во внутренние и внешние дела друг друга и др.[55]

Собственные принципы международного регионального права как отрасли международного права можно сгруппировать на специальные отраслевые и специальные институционные принцииы.

К специальным отраслевым принципам международного регионального права следует отнести принципы, которые отражают специфику международного регионального права как отрасли международного права:

- принцип целесообразности и обоснованности создания нового регионального объединения;

- принцип обеспечения взаимной заинтересованности участников регионального объединения;

- принцип добровольности вхождения субъекта международного права в региональную структуру;

- принцип разноуровневой и разноскоростной интеграции и т.д.

Специальные институционные принципы международного регионального права составляют общие начала, которые лежат в основе того или иного регионального объединения. Например, исходя из ст. 4 Учредительного акта Африканского союза можно выделить следующие специальные институционные принципы:

- взаимозависимость государств-членов союза;

- участие африканских народов в деятельности союза; 
- формирование общей оборонной политики африканского континента;

- право союза на вмешательство в дела государств по решению Ассамблеи при совершении военных преступлений и преступлений против человечества, а также геноцида;

- право государств - членов на обращение в союз с целью его вмешательства для восстановления мира и безопасности;

- гендерное равенство;

- осуждение и отказ от неконституционной смены правительств.

В ст. 5 Договора об учреждении ЕС к таким принципам, например, относятся принцип законности (деятельность ЕС должна осуществляться строго в соответствии с целями его создания, а также в рамках тех полномочий, которыми он наделен), принцип субсидиарности (ЕС не вправе вмешиваться в дела государства - его участника, если последнее в состоянии эффективно решать их самостоятельно, за исключением вопросов, отнесенных к исключительной компетенции ЕС), принцип пропорциональности (все действия ЕС должны строго соответствовать целям создания ЕС).

\section{Принцип прямого действия права международного регионального объединения}

Среди специальных институционных принципов международного регионального права целесообразно более подробно рассмотреть такой принцип, как принцип прямого действия права регионального объединения, поскольку он лежит в основе тех региональных организаций, которые достигли высокого уровня интеграции (EC, в рамках ТС и ЕЭП и т.д.).

Названный принцип означает, что акты региональной организации распространя- ют свое действие не только на государства - члены регионального объединения, но и непосредственно на физических и юридических лиц, которые вправе при рассмотрении конкретных дел в национальных судах ссылаться напрямую на нормы актов, принятых в рамках региональной структуры.

Его реализация зависит от вида источника регионального права организации:

- нормы регламентов, которые действуют в полном объеме и не могут быть подменены национальным законодательством;

- нормы учредительных договоров имеют прямое действие только в том случае, если они прямо закрепляют субъективные права и обязанности, включая обязанности государств - участников регионального объединения. Так ст. 23 Договора о Европейском союзе 1957 года предусматривает отмену внутри данной организации всех таможенных пошлин или эквивалентных сборов. В случае, если какое-либо государство потребует от хозяйствующего субъекта ее уплаты, последний вправе обратиться в суд.

Эта норма содержит четкое правило поведения и является нормой прямого действия. А ст. 136 этого же акта, в соответствии с которой «Сообщество и государства - члены... ставят целями содействие занятости, улучшение условий жизни и труда...» носит декларативный характер и не является нормой прямого действия.

Обобщая изложенное, можно сделать вывод о том, что на сегодняшний день в рамках международного права формируется его структурная часть, которая базируется на сложной системе принципов, включающей в себя общепризнанные принципы международного права, специальные отраслевые принципы и специальные институционные принципы международного регионального права. 
DOI: $10.7256 / 2226-6305.2015 .3 .16209$

При цитировании этой статьи сноска на dоі обязательна

Международное право и международные организации•3•2015

International Law and International Organizations

\section{Систематизация и структуризация международного регионального права}

Международное региональное право является отраслью международного права. Учитывая большое количество созданных региональных организаций, а соответственно, значительного количества источников регионального права (как первичного, так и вторичного права), а также принимая во внимание специфику каждой из региональных организаций, важное значение имеют вопросы систематизации и структурирования международного регионального права.

При этом систематизация и структуризация международного регионального права представляет собой внутреннюю структуру права такого огромного комплекса, что структуризация входящих в него норм права вызывает определенные сложности в формировании элементов международного регионального права.

\section{Структуризация международного регионального права}

Проблемы при структуризации вызваны рядом причин. Это и различный уровень интеграции государств в рамках тех или иных региональных объединений, разнообразная внутренняя структура каждой региональной организации, существенные различия в порядке принятия решений и юридической силе таких решений, а также многие другие факторы.

Кроме того, несмотря на более чем столетнюю историю некоторых региональных организаций, можно говорить о том, что такие объединения и на сегодняшний день находятся в процессе активного развития. Так, Южноафриканский таможенный союз (ЮАТС) считается одним из самых старых таможенных союзов в мире. Он относится ко времени Конвенции о Таможенном союзе 1889 года между британской Колонией Мыса Доброй Надежды и бурской республикой Оранжевого Свободного Государства.

29 июня 1910 года между Басутолендом, Свазилендом и Протекторатом Бечуаналенда было принято Соглашение ЮАТС, которое вступило в силу с 1 июля 1910 года и действовало вплоть до 1969 года. Несмотря на достигнутые значительные достижения сторон в рамках Соглашения 1910 года (был введен общий внешний тариф (ОВТ) на все импортируемые из третьих стран в страны Союза товары; установлен общий пул таможенных пошлин согласно суммарному объему внешней торговли; введен акцизный сбор, основанный на полном производстве и потреблении подлежащих обложению акцизом товаров и т.д.), нельзя сказать, что Союз полностью достиг поставленных перед ним целей. Пересмотренное Соглашение 2002 года было подписано сторонами с учетом сложившихся реалий мировой регионализации и глобализации, с учетом новых задач, расширяющих процессы интеграции «вглубь» и «вширь», соответственно стала формироваться новая правовая база ЮАТС.

Говоря о формировании в системе международного права международного регионального права, необходимо также учитывать, что, как и любая иная система, ее внутренние элементы должны быть согласованы и находиться в постоянной взаимосвязи.

Именно поэтому на данной стадии формирования международного регионального права можно говорить исключительно о становлении и развитии искомых критериев его систематизации и структурирования.

Наиболее значимые успехи в формировании различных правовых объединений (структурных элементов) международного регионального права достигнуты в рамках 
Европейского союза, который был создан в 1992 году. Однако многие западные ученые считают, что, например, административное право Евросоюза только сейчас начинает приобретать некоторые очертания. На это направлены усилия многих структурных органов ЕC, к числу которых, в первую очередь, относится Суд Европейского Союза (European Court of Justice)[56].

Аналогичная ситуация, именуемая в литературе процессом европеизации, применима и к иным правовым блокам права Евросоюза[57]. Большинство же правовых блоков Евросоюза находятся на стадии формирования. Как отмечают иностранные специалисты, исходя из уровня подготовки европейского гражданского кодекса в 2000-ые годы совершенно очевидно, что этот кодекс не может быть разработан в ближайшем будущем и что реальное время его появления весьма трудно, если вообще возможно, предсказать[58].

Один из участников рабочей группы по разработке европейского гражданского кодекса профессор Католического Университета в Лувене Матиас Е. Шторме отмечает: «...нашей целью было создание модельного закона, который смог бы улучшить и гармонизировать национальные законы европейских государств, потому что являлся бы плодом глубоких научных исследований в области сравнительного права»[59]. Несмотря на пессимистические прогнозы ряда ученых, работа над проектом европейского гражданского кодекса была завершена в 2008 году, когда он и был представлен на рассмотрение Комиссии ЕС. Проект кодекса содержит определения и устанавливает типовые правила, которые направлены на регулирование широкого круга имущественных отношений, в том числе закрепляет общие положения о договорах, сделках, деликтах, обязательствах, а также регулирует специальные коммерческие контракты, потребительские договоры и трасты. Однако до настоящего времени официальной информации о принятии данного акта нет.

\section{Подотрасли и институты} международного регионального права

В соответствии с принятой структуризацией международного права, а также по аналогии со структуризацией национального права, в рамках международного регионального права следует выделить подотрасли и институты.

В целях действенной (универсальной) систематизации и структуризации международного регионального права на подотрасли в качестве системообразующего критерия целесообразно использовать региональный признак, т.е. в основе деления норм на подотрасли предлагается использовать региональный аспект. Как показывает практика регионализации, в региональные группы страны объединяются как по территориальному и социальному, так и по функциональному принципу (общность доктрин). Перед такими странами, как правило, стоят схожие проблемы, решение которых требует совместных усилий. Классическими примерами таких региональных организаций являются Евросоюз, Африканский союз и т.д.

Еще один довод в пользу выбранного критерия заключается в том, что государства одного условного региона, как правило, являются участниками (членами) иных субрегиональных организаций, которые, в свою очередь, большей частью функционируют в пределах того же региона, что оказывает влияние на их систему права.

Кроме того, в уже сложившихся регионах, в большинстве случаях действует специфическая система права. В Европе и Северной 
Америке параллельно функционируют континентальная и англо-саксонская системы права. Завоевание колонизаторами Латинской Америки и Карибского архипелага оказало решающее влияние на гармонизацию их правовых систем. Этот процесс происходил де-факто, в силу влияния норм права метрополий (Испании, Португалии, Франции и Нидерландов)[60].

Аналогичным образом складывалась система права на африканском континенте, основу права каждого африканского государства образуют местные обычаи, а также правовые нормы господствующей страны - колонизатора (право на континенте формировалось еще в период существования колоний и большинство государств в качестве промежуточного решения избрали сохранение законов, принадлежащих государствам-колонизаторам или государствам, обладающим мандатом в отношении этих стран, и действующим на дату обретения независимости [61]).

Значительной спецификой обладает мусульманское право, действующее в регионах мусульманской цивилизации, в том числе в западной и центральной, а также в ряде субрегионов восточной Азии. В правовой системе мусульманского права кроме правовых норм действуют также религиозные нормы.

Отличительными особенностями обладает также индусское право: традиционное право, с одной стороны, черпающее свои основные источники из религии, современное право - с другой, обязанное английскому праву многими своими традициями[61]. При этом при создании региональных объединений, при образовании новых экономических, социальных, военно - политических пространств, происходит смешивание существующих правовых систем, начинают формироваться новые правовые пространства, включающие в себя элементы различных правовых систем, различных правопорядков.

С учетом проводимой в рамках региональных объединений унификации и стандартизации национальных систем права, именно региональный признак с позиции формирования институтов международного регионального права наиболее удачен.

Кроме того, использование регионального признака в качестве критерия для выделения институтов международного регионального права позволит в дальнейшем выявить определенные закономерности в интеграционных процессах в крупных регионах. Исходя из такого подхода к делению международного регионального права на подотрасли, можно выделить: Евразийское право, Европейское право, региональное право Азии и Океании, Африканское право, Американское право.

В качестве шестой подотрасли международного регионального права с учетом тенденций нового регионализма необходимо выделять межрегиональное право, регулирующее трансгрегиональные взаимоотношения стран и региональных организаций, не имеющих общих внешнеэкономических или внешнеполитических доктрин. Эту подгруппу составляют межрегиональные объединения, представляющие собой нейтральные площадки: (Саммит Африка - Южная Америка, Саммит ИВСА (Индия, Бразилия. Южная Африка, Саммит США - Африка), Группа 20 и т.д.

Поскольку критерий деления международного регионального права на подотрасли отличает достаточно общий и условный признак регионального деления, следует учитывать, что в рамках каждого континента действует определенное количество отдельных субрегиональных организаций, со своими собственными целями, организационной структурой, численным составом их участни- 
ков и иными особенностями. Каждое субрегиональное объединение имеет собственную правовую базу, на основании которой решаются все организационные и иные вопросы. Таким образом, в качестве критерия деления регионального права на институты предлагается использовать критерий «субрегиона», иными словами институтами регионального права являются системы права каждого отдельного субрегионального объединения.

Например, в европейском региональном праве можно назвать такие институты как право Совета Европы, право Евросоюза, право Северного совета и т.д.

В региональном праве Африки следует выделить в качестве институтов право Африканского союза, право Восточноафриканского сообщества, право Организации по гармонизации предпринимательского права в Африке (ОХАДА), право Южноафриканского сообщества развития (САДК), право Организации общего рынка Восточной и Южной Африки (КОМЕСА), право Экономического сообщества центральноафриканских государств (ЭККАС), право Экономического сообщества западноафриканских государств (ЭКОВАС) и т.д.

В структуру институтов евразийского права должно входить право таких организаций как Содружество Независимых государств (СНГ); Союзное государство Беларуси и России (СГ); Евразийский экономический союз (ЕАЭС); Организация договора о коллективной безопасности (ОДКБ);

Шанхайская организация сотрудничества (ШОС); Организация черноморского экономического сотрудничества (ОЧЭС); Организация за демократию и экономическое развитие (ГУАМ); Совещание по взаимодействию и мерам доверия в Азии (СВМДА); Содружество демократического выбора (СДВ); Совет сотрудничества тюркских государств (ССТГ,
Тюркский совет); Союз персоязычных государств; Саммит БРИКС;

Саммит каспийских государств и других евразийских организаций, саммитов и форумов.

\section{Систематизация международного регионального права как научного направления и как учебной дисциплины}

Любая правовая общность должна быть систематизирована. Поэтому особого внимания заслуживает вопрос о систематизации международного регионального права не только как научного направления, но и как учебной дисциплины. Представляется, что современный подход, когда правовое регулирование в сфере региональной интеграции изучается в рамках существующих дисциплин попутно, устарел. В этой связи необходим противоположный подход - внедрение в учебный процесс дисциплины комплексного характера, которая предметно изучала бы международное региональное право с упором как на евразийское право, так и на мировой опыт.

Поскольку правовая наука призвана изучать, анализировать и соотносить взаимосвязи «общественные отношения - законодательство - право» система международного регионального права как научной дисциплины должна быть основана на системе международного регионального права как отрасли международного права. Вместе с тем международное региональное право как научная дисциплина имеет свои особенности, основанные на теоретических аспектах познания.

В связи с этим в международное региональное право как научную дисциплину должен быть включен комплекс таких теоретических вопросов, как понятие и виды региональной интеграции; основные теории 
интеграции; понятие, предмет и принципы международного регионального права; методы правового регулирования и источники международного регионального права, а также исторические аспекты региональных интеграционных процессов. Особое внимание должно быть уделено теоретическим проблемам, возникающим при формировании и развитии международного регионального права как научной дисциплины.

Схематически международное региональное право (МРП) как научная дисциплина может быть выражена следующим образом.

\section{1.Общая часть}

1.1. Историко -правовые аспекты региональной интеграции

1.2. Понятие и виды региональной интеграции

1.3. Основные теории региональной интеграции

1.4. Понятие и принципы международного регионального права

1.5. Предмет международного регионального права

1.6. Методы международного регионального права

1.7. Источники международного регионального права
1.8. Субъекты международного регионального права

1.9. Структура международного регионального права

2. Особенная часть

2.1. Евразийское право

2.2. Европейское право

2.3. Региональное право Азии и Океании

2.4. Африканское право

2.5. Американское право

2.6. Межрегиональное право

Система международного регионального права как учебной дисциплины по сравнению с международным региональным правом как правовой науки также должна иметь определенные особенности, связанные с подготовкой кадров в различных областях общественной жизни. Специфика международного регионального права как учебной дисциплины, в первую очередь, должна быть направлена на удобство (полнота, последовательность) изложения материала, которое способствовало бы надлежащей подготовке студентов. При этом в процессе преподавания дисциплины во внимание должны всесторонне приниматься и научные аспекты международного регионального права.

\section{Библиография:}

1. Administrative Law of the European Union, Its Member States and the United States. A Comparative Analysis / Ed. by R. Seerden. Oxford, 2007.

2. Fernandez Arroyo D.P. La Codificación del Derecho Internacional Privado en América Latina, Madrid, 1993pp. 155; Вилкова Н.Г. Договорное право в международном обороте. М.: Статут, 2004.

3. Garro A. Unification and Harmonization of Private Law in Latin America// The American Journal of Comparative Law vol.40. № 3.1992

4. Jansen N. European Civil Code // Elgar Encyclopedia of Comparative Law / Ed. by J. Smits. Cheltenham, 2006. P. 248.

5. Kelsen, H. Principles of International Law. 2nd ed. New York; Chicago; San Francico; Toronto; London, 1967.

6. Matthias E. Storme. Une question de principe? Reponse a quelques critiques a l'egard du projet provisoire de «Cadre commun de reference». ERA Forum (2008) 9:S67.

7. O'Keefe T.A. Resurgent MERCOSUR: Confronting Economic Crises and Negotiating Trade Agreements // A North-South Agenda Paper (University of Miami). 2003. January. P. 11. 
8. Peter Draper. Breaking Free from Europe: Why Africa Needs Another Model of Regional Integration. // Regionalism in a Changing World. Comparative Perspectives in the New Global Order. Edited by Larenzo Fioramonti. London and New York: Routladge, 2013.

9. Ratnapala S. Jurisprudence. Cambridge, 2009.

10. Vandervort, Thomas L. R. International Law and Organization. - Dortrecht, 1996.

11. Алексеев С. С. Структура советского права. М. Юридическая литература. 1975.

12. Вирко Н.А. Международное право. - М.: Эксмо, 2007.

13. Гаврилов В.В. Понятие и взаимодействие международной и национальных правовых систем. Владивосток, 2005.

14. Гарсия-Гарридо М.Х. Римско-правовое наследие в кодексах Латинской Америки // Римское частное и публичное право: многовековой опыт развития европейского права: Материалы заседаний IV Международной конференции. Москва-Иваново-Суздаль, 25-30 июня 2006 г.

15. Гражданское право. В 2 т. Т. 1 / Отв. ред. Е.А. Суханов. 2-е изд., перераб. и доп. М., 1998.

16. Гуреев С. А. Международное морское право (понятие, становление как отрасли). Советский Ежегодник международного права, 1980.М. Наука. 1982.

17. Долгополова М.В. О предмете правового регулирования // История гос-ва и права. 2009. № 14. С. 42 - 46; Лазарев В.В. Общая теория права и государства. М.: Норма; Инфра-М, 1999.

18. Ерпылева Н.Ю., Максимов Д.М. Правовой статус межправительственной организации по международным железнодорожным перевозкам // Международное право и международные организации. 2012. № 4.

19. Кашкин С.Ю., Ядрихинская О.А. История становления и развития науки Европейского права в России / История юридических наук в России. - М.: МГЮА, 2009.

20. Кривчикова Э.С. Основы теории права международных организаций. - М.: МГИМО, 1979;

21. Лаптев В.В. Предпринимательское право: понятие и субъекты. М.: Юристъ. 1997.

22. Лукашук И.И. Международное право. Изд. 3-е. - М.: Волтерс Клувер, 2005

23. Международное право. Основы теории: Под ред. В. Г. Буткевич. - М.: Просвещение. 2002.

24. Лукашук И.И. Международное право. Общая часть. М., 1996.

25. Лукашук И.И. Механизм международно-правового регулирования. Киев, 1980.

26. Лунц Л. А. Развитие советской доктрины по международному частному праву / Советское государство и право. 1977. № 12. С. 49; Богуславский М. М.: .Международное частное право. - М.: Международные отношения, 1974.

27. Малинин С. А. Мирное использование атомной энергии. Международно-правовые вопросы. - М.: Международные отношения, 1971. С. 7.

28. Маргиев В И. О системе международного права. - Правоведение, 1981. № 2.

29. Маргиев В. И. О системе международного права / Правоведение. 1981. - № 2. С. 79.

30. Марочкин С.Ю. Действие и реализация норм международного права в правовой системе Российской Федерации: Монография. М.: Норма, Инфра-М, 2011.

31. Марченко М.Н. Общая теория права. М.: Проспект, 2004.

32. Марченко М.Н., Дерябина Е.М. Правовая система Европейского союза: монография. М.: Норма, Инфра-M, 2012

33. Матвеев Г. К. Предмет, система и задачи дальнейшего развития международного частного права. «СЕМП 1978». - М.: Наука, 1980.

34. Международное воздушное право. Книга 1. М.: Наука. 1980.

35. Международное право / отв. ред. Г.В. Игнатенко, О.И. Тиунов. 3-е изд., перер. и дополн. М.: Норма. 2005.

36. Международное право 2-е издание. / Под редакцией А.Н.Вылегжанина. М.: Юрайт, $2012 .$.

37. Международное право. М.: Юридическая литература, 1974

38. Международное право. Общая часть. Г.Я. Бакирова, П.Н. Бирюков, Р.М. Валеев и др.; отв. ред. Р.М. Валеев, Г.И. Курдюков. М.: Статут, 2011.

39. Международное право. Свердловск, 1974.

40. Международное публичное право. отв. ред. К. А. Бекяшев. М.: Проспект, 2011. 
41. Мюллерсон Р. А. О соотношении международного публичного, международного частного и национального права. - Советское государство и право. 1982. № 2. С. 86-88.

42. Общая теория права. Академический курс в 2 т. / Под ред. М.Н. Марченко. М., 1998. Т. 2.

43. Общепризнанные принципы и нормы международного права, международные договоры в практике конституционного правосудия: Материалы Всероссийского совещания / Под ред. М.А. Митюкова и др. М., 2004

44. Оппенгейм Л. Международное право: В 2 т. М., 1948. Т. 1.

45. Оппенгейм Л.М. Международное право. М.: Позис. 2000.

46. Определение Верховного Суда РФ от 01.02.2008 № 80-В07-21 В удовлетворении иска о назначении трудовой пенсии по старости, индексации выплаченной пенсии отказано правомерно, так как одним из обязательных условий назначения пенсии иностранному гражданину является его постоянное проживание на территории РФ // Бюллетень Верховного Суда РФ, 2009, № 1.

47. Полторак А. И., Савинский Л. И. Вооруженные конфликты и международное право. - М.: Наука. 1976. C. 79.

48. Постановление Конституционного Суда РФ от 25.04.2001 № 6-П. По делу о проверке конституционности статьи 265 Уголовного кодекса Российской Федерации в связи с жалобой гражданина А.А. Шевякова // Собрание законодательства РФ, 04.06.2001, № 23, ст. 2408.

49. Постановление Пленума Верховного Суда РФ от 10.10.2003 № 5 (ред. от 05.03.2013) «О применении судами общей юрисдикции общепризнанных принципов и норм международного права и международных договоров Российской Федерации» // Российская газета, № 244, 02.12.2003.

50. Постановление Пленума Верховного Суда РФ от 31.10.1995 № 8 (ред. от 16.04.2013) «О некоторых вопросах применения судами Конституции Российской Федерации при осуществлении правосудия» // Российская газета, № 247, 28.12.1995.

51. Право Европейского Союза. Основы теории и истории. Марченко М.Н., Дерябина Е.М. М.: Проспект, 2010 .

52. Правовые вопросы деятельности СЭВ. - М., 1977.

53. Раймон Леже. Великие правовые системы современности.2-е издание (пер. с фр. Грядов.А.В.). М.: Волтерс Клувер. 2010. С. 266.

54. Российская юстиция. 2003. № 3.

55. Рыжов В.Б. Роль судопроизводства в формировании права МЕРКОСУР // Международное публичное и частное право. 2006. № 5.

56. Статут Международного Суда (принят в г. Сан-Франциско 26.06.1945) // Сборник действующих договоров, соглашений и конвенций, заключенных СССР с иностранными государствами. Вып. ХІІ. - М., 1956.

57. Тихомиров Ю.А. Публично-правовое регулирование: динамика сфер и методов // Журнал российского права. 2001 № 5.

58. Тункин Г.И. Идеологическая борьба и международное право. М., 1967.

59. Тункин Г.И. Теория международного права. М., 2006.

60. Тюрина Н.Е. Публичные правоотношения в международной торговле // Российский юридический журнал. 2011. № 5. С. 55-63.

61. Тюрина Н.Е. Роль наднационального метода в реализации международного права // Правореализация и юридический процесс: инновационные подходы к построению моделей: Сб. ст. междунар. науч. - практ. конф. Казань, 2011.

62. Устав Международного агентства по атомной энергии (МАГАТЭ) (принят 26.10.1956) // Действующее международное право. Т. 3. - М.: Московский независимый институт международного права, 1997.

63. Устав Содружества Независимых Государств (принят в г. Минске 22.01.1993) // Бюллетень международных договоров, № 1, 1994.

64. Черниченко С.В. Очерки по философии и международному праву. Изд-во: Научная книга. 2009.

65. Шибаева Е.А. Право международных организаций. - М., 1986

66. Шибаева Е.А. Право международных организаций. М., 1986. 
67. Яковлев В.Ф. Избранные труды. Т. 2: Гражданское право: история и современность. Кн. 1. М.: Статут, 2012.

68. Курбанов Р.А. Интеграционные процессы в Африке: Управление бассейном реки Нигер // Юридические исследования. - 2015. - 5. - C. 104 - 120. DOI: 10.7256/2409-7136.2015.5.14842. URL: http://www.enotabene.ru/lr/article_14842.html

69. Курбанов Р.А. Региональная интеграция в Африке: Межафриканская конференция социального страхования // Право и политика. - 2015. - 3. - С. 319 - 326. DOI: 10.7256/1811-9018.2015.3.14673.

\section{References (transliterated):}

1. Fernandez Arroyo D.P. La Codificación del Derecho Internacional Privado en América Latina, Madrid, 1993pp. 155; Vilkova N.G. Dogovornoe pravo v mezhdunarodnom oborote. M.: Statut, 2004.

2. Garro A. Unification and Harmonization of Private Law in Latin America// The American Journal of Comparative Law vol.40. № 3. 1992

3. Jansen N. European Civil Code // Elgar Encyclopedia of Comparative Law / Ed. by J. Smits. Cheltenham, 2006. P. 248.

4. Kelsen, H. Principles of International Law. 2nd ed. New York; Chicago; San Francico; Toronto; London, 1967.

5. Matthias E. Storme. Une question de principe? Reponse a quelques critiques a l'egard du projet provisoire de «Cadre commun de reference». ERA Forum (2008) 9:S67.

6. O'Keefe T.A. Resurgent MERCOSUR: Confronting Economic Crises and Negotiating Trade Agreements // A North-South Agenda Paper (University of Miami). 2003. January. P. 11.

7. Peter Draper. Breaking Free from Europe: Why Africa Needs Another Model of Regional Integration. // Regionalism in a Changing World. Comparative Perspectives in the New Global Order. Edited by Larenzo Fioramonti. London and New York: Routladge, 2013.

8. Ratnapala S. Jurisprudence. Cambridge, 2009.

9. Vandervort, Thomas L. R. International Law and Organization. - Dortrecht, 1996.

10. Alekseev S. S. Struktura sovetskogo prava. M. Yuridicheskaya literatura. 1975.

11. Virko N.A. Mezhdunarodnoe pravo. - M.: Eksmo, 2007.

12. Gavrilov V.V. Ponyatie i vzaimodeistvie mezhdunarodnoi i natsional'nykh pravovykh sistem. Vladivostok, 2005.

13. Garsiya-Garrido M.Kh. Rimsko-pravovoe nasledie v kodeksakh Latinskoi Ameriki // Rimskoe chastnoe i publichnoe pravo: mnogovekovoi opyt razvitiya evropeiskogo prava: Materialy zasedanii IV Mezhdunarodnoi konferentsii. Moskva-Ivanovo-Suzdal', 25-30 iyunya $2006 \mathrm{~g}$.

14. Gureev S. A. Mezhdunarodnoe morskoe pravo (ponyatie, stanovlenie kak otrasli). Sovetskii Ezhegodnik mezhdunarodnogo prava, 1980.M. Nauka. 1982.

15. Dolgopolova M.V. O predmete pravovogo regulirovaniya // Istoriya gos-va i prava. 2009. № 14. S. 42 - 46; Lazarev V.V. Obshchaya teoriya prava i gosudarstva. M.: Norma; Infra-M, 1999.

16. Erpyleva N.Yu., Maksimov D.M. Pravovoi status mezhpravitel'stvennoi organizatsii po mezhdunarodnym zheleznodorozhnym perevozkam // Mezhdunarodnoe pravo i mezhdunarodnye organizatsii. 2012. № 4.

17. Kashkin S.Yu., Yadrikhinskaya O.A. Istoriya stanovleniya i razvitiya nauki Evropeiskogo prava v Rossii / Istoriya yuridicheskikh nauk v Rossii. - M.: MGYuA, 2009.

18. Krivchikova E.S. Osnovy teorii prava mezhdunarodnykh organizatsii. - M.: MGIMO, 1979;

19. Laptev V.V. Predprinimatel'skoe pravo: ponyatie i sub"ekty. M.: Yurist". 1997.

20. Lukashuk I.I. Mezhdunarodnoe pravo. Izd. 3-e. - M.: Volters Kluver, 2005

21. Lukashuk I.I. Mezhdunarodnoe pravo. Obshchaya chast'. M., 1996.

22. Lukashuk I.I. Mekhanizm mezhdunarodno-pravovogo regulirovaniya. Kiev, 1980.

23. Lunts L. A. Razvitie sovetskoi doktriny po mezhdunarodnomu chastnomu pravu / Sovetskoe gosudarstvo i pravo. 1977. № 12. S. 49; Boguslavskii M. M.: .Mezhdunarodnoe chastnoe pravo. - M.: Mezhdunarodnye otnosheniya, 1974. 
24. Malinin S. A. Mirnoe ispol'zovanie atomnoi energii. Mezhdunarodno-pravovye voprosy. - M.: Mezhdunarodnye otnosheniya, 1971. S. 7.

25. Margiev V I. O sisteme mezhdunarodnogo prava. - Pravovedenie, 1981. № 2.

26. Margiev V. I. O sisteme mezhdunarodnogo prava / Pravovedenie. 1981. - № 2. S. 79.

27. Marochkin S.Yu. Deistvie i realizatsiya norm mezhdunarodnogo prava v pravovoi sisteme Rossiiskoi Federatsii: Monografiya. M.: Norma, Infra-M, 2011.

28. Marchenko M.N. Obshchaya teoriya prava. M.: Prospekt, 2004.

29. Marchenko M.N., Deryabina E.M. Pravovaya sistema Evropeiskogo soyuza: monografiya. M.: Norma, Infra-M, 2012

30. Matveev G. K. Predmet, sistema i zadachi dal'neishego razvitiya mezhdunarodnogo chastnogo prava. «SEMP 1978». - M.: Nauka, 1980.

31. Myullerson P. A. O sootnoshenii mezhdunarodnogo publichnogo, mezhdunarodnogo chastnogo i natsional'nogo prava. - Sovetskoe gosudarstvo i pravo. 1982. № 2. S. 86-88.

32. Oppengeim L. Mezhdunarodnoe pravo: V 2 t. M., 1948. T. 1.

33. Oppengeim L.M. Mezhdunarodnoe pravo. M.: Pozis. 2000.

34. Poltorak A. I., Savinskii L. I. Vooruzhennye konflikty i mezhdunarodnoe pravo. - M.: Nauka. 1976. S. 79.

35. Raimon Lezhe. Velikie pravovye sistemy sovremennosti.2-e izdanie (per. s fr. Gryadov.A.V.). M.: Volters Kluver. 2010. S. 266.

36. Ryzhov V.B. Rol' sudoproizvodstva v formirovanii prava MERKOSUR // Mezhdunarodnoe publichnoe i chastnoe pravo. 2006. № 5.

37. Tikhomirov Yu.A. Publichno-pravovoe regulirovanie: dinamika sfer i metodov // Zhurnal rossiiskogo prava. 2001 № 5.

38. Tunkin G.I. Ideologicheskaya bor'ba i mezhdunarodnoe pravo. M., 1967.

39. Tunkin G.I. Teoriya mezhdunarodnogo prava. M., 2006.

40. Tyurina N.E. Publichnye pravootnosheniya v mezhdunarodnoi torgovle // Rossiiskii yuridicheskii zhurnal. 2011. № 5. S. 55-63.

41. Tyurina N.E. Rol' nadnatsional'nogo metoda v realizatsii mezhdunarodnogo prava // Pravorealizatsiya i yuridicheskii protsess: innovatsionnye podkhody k postroeniyu modelei: Sb. st. mezhdunar. nauch. - prakt. konf. Kazan', 2011.

42. Chernichenko S.V. Ocherki po filosofii i mezhdunarodnomu pravu. Izd-vo: Nauchnaya kniga. 2009.

43. Shibaeva E.A. Pravo mezhdunarodnykh organizatsii. - M., 1986

44. Shibaeva E.A. Pravo mezhdunarodnykh organizatsii. M., 1986.

45. Yakovlev V.F. Izbrannye trudy. T. 2: Grazhdanskoe pravo: istoriya i sovremennost'. Kn. 1. M.: Statut, 2012.

46. Kurbanov R.A. Integratsionnye protsessy v Afrike: Upravlenie basseinom reki Niger // Yuridicheskie issledovaniya. - 2015. - 5. - C. 104 - 120. DOI: 10.7256/2409-7136.2015.5.14842. URL: http://www.e-notabene.ru/ lr/article_14842.html

47. Kurbanov R.A. Regional'naya integratsiya v Afrike: Mezhafrikanskaya konferentsiya sotsial'nogo strakhovaniya // Pravo i politika. - 2015. - 3. - C. 319 - 326. DOI: 10.7256/1811-9018.2015.3.14673. 